Article

\title{
Green Finance Development in Bangladesh: The Role of Private Commercial Banks (PCBs)
}

\author{
Guang-Wen Zheng ${ }^{1}$, Abu Bakkar Siddik ${ }^{1, * \mathbb{D}}$, Mohammad Masukujjaman ${ }^{2} \mathbb{D}$, Nazneen Fatema ${ }^{3}$ and \\ Syed Shah Alam 4,5,*
}

1 School of Economics and Management, Shaanxi University of Science and Technology (SUST), Xi'an 710021, China; zgw0902@163.com

2 Department of Business Administration, Northern University Bangladesh, Dhaka, Banani C/A, Dhaka 1213, Bangladesh; masuknub@gmail.com

3 Department of Economics and Banking, International Islamic University Chittagong (IIUC) 154/a College Road, Chittagong 4203, Bangladesh; nazneen.fatema@yahoo.com

4 Faculty of Business, Finance and Information Technology, MAHSA University, Jenjarom 42610, Malaysia

5 Faculty of Management and Business, Jalan Universiti Off, KM 12, Jalan Muar, Kemajuan Tanah Jementah Batu Sebelas, Segamat 85000, Malaysia

* Correspondence: absiddik.nub@yahoo.com (A.B.S.); syed@mahsa.edu.my (S.S.A.)

Citation: Zheng, G.-W.; Siddik, A.B.; Masukujjaman, M.; Fatema, N.; Alam, S.S. Green Finance Development in Bangladesh: The Role of Private Commercial Banks (PCBs). Sustainability 2021, 13, 795. https:// doi.org/10.3390/su13020795

Received: 13 December 2020 Accepted: 12 January 2021 Published: 15 January 2021

Publisher's Note: MDPI stays neutral with regard to jurisdictional clai$\mathrm{ms}$ in published maps and institutional affiliations.

Copyright: (C) 2021 by the authors. Licensee MDPI, Basel, Switzerland. This article is an open access article distributed under the terms and conditions of the Creative Commons Attribution (CC BY) license (https:// creativecommons.org/licenses/by/ $4.0 /)$.

\begin{abstract}
Green finance (GF) has been gaining significant attention in recent literature, owing to the rise in global actions against the climate change. It is conceptually ambiguous, with no conclusive agreement among researchers on its meaning. Therefore, the main purpose of the study is to identify the bankers' perception of various dimensions of GF, and identify the major challenges affecting its implementation in Bangladesh. Besides, this study also reveals the status of GF in Bangladesh's banks and non-bank financial institutions from 2014 to 2019. In order to define the key aspects of GF through the data obtained from 296 banking staffs of private commercial banks (PCBs) in Bangladesh, confirmatory factor analysis (CFA) was used. The study also used descriptive statistics to identify the major challenges hindering the development of GF in Bangladesh. The findings of this study show that, in comparison with other banks and non-bank financial institutions, the PCBs are the largest contributors to direct GF, accounting for $74.2 \%$ of the total GF in Bangladesh. The outcomes of the study also identify the "economic dimension" as the most significant dimension affecting the level of bankers' perceptions of GF. Moreover, the bankers perceived the "social and environmental dimensions" as being the second and third most crucial factors influencing GF, followed by sources of green financing. The empirical findings indicate that bankers of PCBs deemed the level of awareness, beliefs and understanding of the major dimensions of GF and sources of green financing to be satisfactory for the implementation of GF in Bangladesh. In addition, the study also shows that high transaction costs, heavy default culture, operational self-insufficiency, improper appraisal of loan applications, and the absence of adequate accountability and transparency are the major barriers to the development of GF in Bangladesh. Therefore, major policy implications are further discussed.
\end{abstract}

Keywords: green finance; bankers' perception; banks; CFA; Bangladesh

\section{Introduction}

The planet has witnessed an intense reinforcement of natural events, such as winds, floods and heat waves, due to the rapid dissolution of glaciers and polar ice caps, resulting from environmental deterioration. Environmental issues such as ecological imbalances, biodiversity loss, soil degradation and ecological destruction are becoming the concerns of global economy and international politics, as they have been closely associated with sustainable growth and human survival [1]. Therefore, the implementation of an efficient green economy through green finance represents an important alternative and an avenue for economic growth in developing countries, as well as a channel to ensure sustainability 
via low energy use, consumption and emissions [1,2]. Moreover, climate change is one of the greatest challenges in the world [3]. Developing countries are at a decisive moment, as they are more sensitive to climate change and highly dependent on established global climate finance to support climate protection and mitigation programs. However, many developing countries that have tried to access this financial support have been facing problems, resulting from their lack of successful institutions with experience in project design and planning [3].

Bangladesh is considered to be one of the next emerging economies in the world, with tremendous investment, development and economic potential to become a leading market in the twenty-first century [4]. However, developing countries like Bangladesh are struggling with the challenges of climate change and its related environmental consequences. As an instance, Bangladesh is reported to be one of the most vulnerable countries to weather changes due to rising global sea levels that have degraded natural habitats and increased the population's economic hardship [5]. Consequently, they have implemented various strategies to mitigate the threats and environmental consequences of climate change [6]. This includes the prevention of environmental deterioration and the promotion of sustainable development via formal and coordinated green investment in line with the global norm. Zhang et al. [7] stressed green finance as a vital financial instrument in any country's sustainable economic growth, while Haque and Murtaz [8] also noted that green banking or green finance is one of the major aspects of sustainable economic development in a country such as Bangladesh. Therefore, it can be said that the green financing plays an important role in the suppression of climate change issues and the achievement of sustainable development goals (SDGs) in any country.

In the worlds of academia and business, concepts of green finance-also used synonymously with green investments-are widespread and have various connotations [9]. Green finance is an evolving idea [1], with no formal and global definition [10]. Green finance is the best alternative to financing ecofriendly projects and agencies that protect the ecosystem. It considers positive and effective environmental results, even in the financing of tasks in various eco-friendly activities, such as renewable electricity, efficiency in strength, green industry establishment, green brick manufacturing, clean energy, pollution management, water management, climate change mitigation and adoption strategies, biodiversity safety, etc. Therefore, the development of green finance, which improves the progress and transition of green economy, allows people to address the issues of climate change, environmental crises and energy conservation. Besides this, a scale-up of funding is needed for investment that provides economic and environmental advantages through new financial tools and new policy initiatives, such as green banks, central banks, green bonds, fintech and energy market tools, to attain the SDGs. Green finance combines financial decisions with environmental commitments in order to produce optimum results [11].

There are issues with green finance in almost all of the countries around the world, and these are particularly severe in developing nations whose economic growth relies on the development of oil and natural gas [12]. More recently, Fedorova [12] studied the problems related to the development of green finance in Russia. The study identified a number of issues specific to green finance, which include disagreements on the understanding of the principles of green finance and economy; difficulties in evaluating and assessing the external effect of green finance; structural factors hindering the growth of green finance; knowledge imbalance; and issues related to the estimation of credit. It is now generally accepted that green finance is not only beneficial to the ecosystem, but also to the investors. Other than these advantages and its relevance to environment issues, green finance also has disadvantages, such as low yields, complicated processes and a lack of expertise [10]. Green projects-despite having strong externalities and environmental advantages compared to the conventional ones-lack professional experience, and are costly at the early developmental stages $[13,14]$. The enthusiasm of companies to involve themselves in green projects development would be hampered by the green project mediator, information resources, and other specialist institutions. The method of developing 
green finance needs creative talents, such as those related to finance and environmental economics. Therefore, it can be said that the lack of talents, low returns, complicated procedures and high implementation costs make the sustainable development of green finance inadequate in developing countries.

Recently, numerous studies have been conducted worldwide on green finance [6,10,15-18]. These studies mostly focused on the recent trends, problems and opportunities for the development of green finance to achieve sustainable development goals (SDGs). Besides this, a few studies have attempted to identify the relationship between green finance and green economy in China [1]; green finance and climate change mitigation in N-11 (next 11 emerging countries) and (Brazil, Russia, India, China, and South Africa) BRICS countries [4]; and green finance, carbon intensity and non-fossil energy consumption in China [19]. Although several existing studies have emphasize the practices, prospects, challenges and sustainable reporting of green banking in the Bangladesh context, bankers' perceptions regarding the major dimensions of green finance (social, economic and environmental) and sources of green financing remain largely unexplored. Additionally, there exist limited studies in the direction of green finance dimensions based on the primary data.

As such, this study attempts to fill the above research gap in the following ways: first, this paper shows the present status of green finance in Bangladesh. Second, the study analyzes the bankers' perceptions regarding various dimensions of green finance and the sources of green financing in the private commercial banks (PCBs) in Bangladesh. Third, this research also identifies the major challenges hampering the development of green finance in Bangladesh using primary data. In achieving the aforementioned objectives, this study seeks to answer the following two questions: (1) what are bankers' perceptions of the main aspects of green finance and the sources of green financing in Bangladesh's private commercial banks? (2) What are the major barriers to the implementation of green finance in Bangladesh?

This study differs in at least three major aspects in comparison with the existing literature. First, bankers' perceptions regarding the different aspects of green finance (social, economic and environmental) have been utilized in this study. Second, the analysis also considered the perceptions of bankers regarding the main projects of green finance, including renewable energy, alternative energy, factory safety and security, energy efficiency, waste management, recycling and recyclable products, green brick manufacturing and green tourism. Third, this study also identifies the major challenges in the implementations of green finance in Bangladesh.

The remainder of the paper is structured as follows. Section 2 presents the recent literature on green finance dimensions, its challenges and status in commercial banks of Bangladesh. Section 3 advances the sampling, data collection, research instruments, and data analysis process. Section 4 addresses the empirical observations and discussion, subsequent to the conclusion of the report with major policy consequences, limitations and suggestions for future studies in Sections 5 and 6.

\section{Literature Review}

Scholars, researchers and practitioners are now increasingly dedicating their research to the topic of sustainable economic growth, green banking and green finance. The financial sector, on the other hand, is considered an indispensable sector of the economy with a possible intermediary role between sustainable economic improvement and environmental protection. However, it is often directly or indirectly implicated in the maintenance and degradation of environmental sustainability [20]. Although the idea of green finance is still under development in Bangladesh, it has drawn great attention in the modern financial sector, as indicated by their issuance of instruments, such as green bonds, green equity and green debenture [10].

Green finance is a rapidly evolving idea [1], with no formal and global explanation for its concept [10]. The purpose of green finance is to harmonize the improvement of monetary events, environmental stability, ecological protection and attainment of SDGs [21]. Simi- 
larly, Wang and Zhi [11] noted that green finance is considered a new monetary event that associates economic advantages with ecological protection. According to Wang et al. [22], green finance can be broadly emphasized by the two latest research topics, namely sustainable development and finance. Zhang et al. [7] highlighted that green finance is viewed as an essential financial instrument for the sustainable economic development of any country, while Haque and Murtaz [8] also regarded green banking and finance as one of the significant dimensions in the development of a sustainable economy in developing countries, such as Bangladesh. As such, the expansion of green finance plays a crucial role in accomplishing the aims of sustainable economic growth and ecological quality improvement [21], and resolving the conflict between the economy and environment [23]. Without economic viability, a company may encounter an early or late liquidation. Therefore, financial sustainability is a necessity for any company, particularly the banking institutions, such as private commercial banks (PCBs), in order to maintain sustainable development [24].

The central bank of Bangladesh is supporting green financing through concessional refinancing programs and credit allocations for financial firms, along with establishing green bank policies and sector-specific transformation projects funded by international donors. Therefore, the green financing system for sustaining green growth and ecological improvements has already been implemented by banks and non-bank financial institutions in Bangladesh [6]. In addition, green banking activities, especially green financing, may reduce the overall internal carbon footprint and external carbon output [5,25]. The dominant players in green financing are the private commercial banks (PCBs) and non-banking financial institutions (NBFIs), as against the state-owned commercial banks (SCBs) and foreign-owned commercial banks (FCBs) in Bangladesh [5,6,26].

Ren et al. [19] examined the relationship between green finance, carbon intensity and non-fossil energy consumption in China based on a vector-error correction model (VECM). The study revealed that China's green finance sector has witnessed rapid success, as the changes in its growth index of green finance coupled with the growing utilization of non-fossil fuel sources have resulted in a decrease in carbon intensity. Similarly, a rise in energy consumption has hindered the growth and use of non-fossil fuel sources, stalled the development of sustainable project investments, and eventually contributed to the decline in the progress of green finance. The study also noted that China's nonfossil energy consumption has been mainly affected by green finance, with strong policydriven consequences.

The relationship between green finance and climate change mitigation in next-11 emerging and BRICS countries was examined [4] using the difference in differences (DID) method from 2005 to 2019 . The study showed that there is no significance difference between the N-11 economies and the BRICS nations in terms of their green finance and climate threats. They also stated that the topic of sustainability is particularly critical for emerging and developing countries. Therefore, they suggested that the $\mathrm{N}-11$ nations and BRICS need to formulate policies by crystallizing the green financing required to resolve the structural risks and vulnerabilities raised by environmental issues. Moreover, the cooperation between green finance and the green economy, aimed at sustainable development in China, was studied by Liu et al. [1]. The study showed that the potential coordination of green finance, green economy and coordinated growth would remain stable. It also stated that green finance has become a new growth point and engine to promote green economic growth, with social responsibility and environmental protection issues being the center of sustainable development.

Climate change is one of the greatest challenges in the world [3]. Developing countries are at a turning point, as they are more susceptible to climate change and are highly reliant on established global climate finance to support climate protection and mitigation programs. However, many developing countries that tried to access this financing have been facing problems due to their lack of successful institutions and experience in project design and planning [3]. 
Although the guidelines for green banking policy are in place, the poor ability of banks and financial institutions to manage green projects has slowed the promotion of green finance. The advantages of green projects are shadowed by high transaction costs [27]. Therefore, despite the policy guidelines, such as the disbursement of at least $5 \%$ of the total green project loan portfolio, banks and financial institutions are unable to find sufficient green project proposals. In addition to the need for the latest technologies for green projects, the underdeveloped market for green products also poses risks. The potential for generating green equity finance remains limited due to the lack of a proper business environment and regulatory framework to attract impactful investments [6]. Green projects usually involve a certain degree of operational risks, owing to the adoption of new technology and the commercialization perspectives. Rawat [10] examined the current advances in green finance based on the published research articles on green finance. He indicated that the lack of attention on the part of stakeholders and unsuccessful government actions has limited the reach of green finance in India. Despite several barriers, green finance study has recently made substantial progress worldwide. It is now generally acknowledged that green finance does not only benefit the ecosystem, but also the investors. Contrary to the several benefits of GF and its significance to environmental issues, low yields, complicated processes and a lack of expertise are among its demerits [10]. The method of developing green finance requires creative talents, such as finance and environmental economics.

There are challenges in almost all of the countries around the world with regards to the implementation of GF, and these are particularly severe in developing nations, where economic growth is dependent on the development of oil and natural gas [12]. More recently, Fedorova [12] studied the problems related to the development of green finance in Russia, and revealed the following: disagreements on the understanding of the principles of green finance and economy; difficulties in evaluating and assessing the external effect of green finance; structural factors hindering the growth of green finance; knowledge imbalance and issues related to the estimation of credit. In another study, Ref. [28] assessed the challenges and opportunities of green finance in the biomass production sector in Italy. The study acknowledged the presence of several institutional and financial functionalities that impede financing options for green projects from companies. These include government policy uncertainty, limited policy support for the commercialization of emerging technologies, limited participation of financial suppliers in the biomass sector, different projected returns of financial suppliers compared to the business objectives of companies, insufficient funding for small-scale investment needs, the short-term focus of investment products, and limited knowledge of green financing and technical proficiency inside businesses. Therefore, it can be said that insufficient knowledge regarding the green financing options and the lack of technical expertise represent the major hindrances of green finance development in developed and developing countries. In other words, it can be noted that the dearth of talent renders the sustainable growth of green finance insufficient in developing countries, such as Bangladesh.

\section{Research Methodology}

\subsection{Sample and Data Collection}

Private commercial banks (PCBs) were particularly selected for this study due to their significant contribution to direct green finance in Bangladesh $[6,26]$. Thus, the main purpose of the study is to identify the bankers' perceptions regarding various dimensions of green finance, and identify the major challenges hindering its implementation in Bangladesh. Besides this, this study also shows the status of the green finance of banks and non-banks financial institutions in Bangladesh from 2014 to 2019. To achieve the aforementioned objectives, primary and secondary data were used in the analysis. The secondary data were obtained from the annual report of Bangladesh Bank during the period of 2014-2019. Primary data were obtained directly from the bankers of the selected private commercial banks (PCBs) in Bangladesh. The participants of the study were chosen using a nonprobability sampling method. A total of 337 questionnaires were distributed, out of which 
296 were retrieved, indicating an effective rate of $87.83 \%$. The data collection was performed confidentially from February to March 2019. The male and female participants constituted $82.1 \%$ and $17.9 \%$ of the respondents, respectively. Among the participants, the majority were middle-aged ( 31 to 40 years of age), $22.2 \%$ were in the $26-30$ age group, while $17.9 \%$ were in the $41-50$ age group. A total of $93.4 \%$ had a master's degree, $5.6 \%$ obtained an undergraduate degree, and only $0.7 \%$ had a PhD degree. Therefore, the empirical results showed that the high education level facilitates bank owners and managers' adoption of the principles of green banking and green finance to protect the environment and maintain a sustainable economy. In terms of the degree of responsibility held by the bankers who participated in the survey, the majority (37.6\%) were officers, $30.2 \%$ were principal officers, followed by senior principal officers and junior officers, accounting for $10.5 \%$ and $16.3 \%$ respectively. Among the respondents, a majority of them carried out the responsibility of managers and assistant managers of the branches. In addition, $60.3 \%$ of respondents had over six years' of working experience, $19.99 \%$ had worked for 3 to 5 years, and $16.66 \%$ served in the bank for up to three years.

\subsection{Study Instrument}

The green finance dimensions were developed based on the current green finance literature, which specifies the factors that affect the structure. To measure these four latent variables, the initial questionnaire included 25 items, namely the economic dimension (ECO) (5 items), social dimension (SOC) (5 items), environmental dimension (ENV) (5 items) and sources of green financing (SGF) ( 6 items). All the measurement items were prepared based on the analysis of relevant literature on green finance and sources of green financing (Table 1). For instance, the initial elements of ECO, SOC and ENV were developed based on the studies of Refs. [5,29]. Similarly, the initial instruments of SGF were formulated based on the investigations of Refs. $[5,6,26]$. Finally, the respondents were also asked to identify the major challenges impeding the implementation of green finance in Bangladesh. The major problems associated with the application of green finance were extracted from past studies $[6,13,27,30-32]$.

Table 1. Study Instruments.

\begin{tabular}{|c|c|c|}
\hline Items & Description & Sources \\
\hline ENV1 & $\begin{array}{l}\text { Reduction in energy consumptions from banking } \\
\text { activities }\end{array}$ & \multirow{4}{*}{$5,29,30$} \\
\hline ENV2 & $\begin{array}{l}\text { Reduction in greenhouse gas emission from } \\
\text { banking activities }\end{array}$ & \\
\hline ENV3 & Energy consumption within the organization & \\
\hline ENV4 & Analysis of clients' environmental risk & \\
\hline SOC1 & $\begin{array}{l}\text { Local community engagement and development } \\
\text { program }\end{array}$ & \multirow{4}{*}[5,29,30]{} \\
\hline SOC2 & Stakeholder engagement plans & \\
\hline SOC3 & Health and safety of the employees & \\
\hline SOC4 & Improvement of brand awareness & \\
\hline ECO1 & Direct economic value generated and distributed & \multirow{4}{*}[5,29,30]{} \\
\hline ECO2 & Financial assistance received from government & \\
\hline ECO3 & Competitive advantage & \\
\hline $\mathrm{ECO} 4$ & Climate change financial implications & \\
\hline SGF1 & Improvement of investment in waste management & \multirow{4}{*}[5,6,26]{} \\
\hline SGF2 & Enhancement of green establishment investment & \\
\hline SGF3 & More investment in green brick manufacturing & \\
\hline SGF4 & $\begin{array}{l}\text { Promotion of investment on recycling and } \\
\text { recyclable product }\end{array}$ & \\
\hline
\end{tabular}

Note: Removed items from the final analysis are not included here. 
In addition, the initial survey instrument statements were updated based on the recommendations of a group of experts, namely seven bank managers, two environmental specialists and five finance professors, in order to verify the reliability of the survey instrument. Subsequent to the review of the questionnaire framework, content and item distribution by the 14 experts, necessary adjustments were made by standardizing, rewriting and replacing many items. The first pilot test of the initial 25-item surveys was conducted among a randomly selected sample of 40 bankers from five commercial banks. After cognitive interviews with pilot sample participants, and reliability and correspondence analysis, nine measuring items (ENV5, ENV6, SOC5, SOC6, SOC7, ECO5, ECO6, SGF5 and SGF6) were removed due to their below- 0.5 correlation item-to-total. Finally, a formal and structured questionnaire containing 16 items was developed. For all of the survey items, the response scale was based on a 5-point Likert scale, with categories ranging from 1 (strongly disagree) to 5 (strongly agree). Consequently, all items were favorably phrased, with a higher score indicating a greater agreement.

\subsection{Data Analysis}

The use of multivariate statistical analysis is highly recommended, as it gives reliable and practical results [33]. Structural equation modeling (SEM) is an example of multivariate analysis, which assesses the relationship between structures. The analytical method described in this research could be characterized as a combination of descriptive statistics and factor analysis. In order to obtain a diversified statistical analysis, the primary data obtained in the surveys were analyzed using SPSS 22.0 and AMOS 23.0. Exploratory factor analysis (EFA) and confirmatory factor analysis (CFA) were employed to assess precision, validity, measurement and structural models. The standardized root mean residual (SRMR) is the square root of the sample-covariance matrix difference, and should be less than 0.08 to suit the model properly [34].

\section{Findings of the Study}

\subsection{Status of Green Finance in Bangladesh}

Although an inclusive green financing strategy is yet to be implemented in Bangladesh, the central bank of Bangladesh is supporting green financing through concessional refinancing programs and credit allocations for financial firms, along with establishing green bank policies and sector-specific transformation projects funded by international donors. Furthermore, the Bangladesh Bank (BB) imposed a compulsory $5 \%$ allocation from the total loan disbursements of all banks and financial institutions towards direct green finance in 2016 [6]. Table 2 displays the total amount of direct disbursements dedicated to green funding by banking and non-banking institutions during the period 2014-2019. Consequently, total amounts of BDT $289,295.08$ and BDT 37,990.97 million were directly disbursed by banks and non-bank financial institution for green financing, respectively. In comparison with other banks and non-bank financial institutions, private commercial banks (PCBs) are the largest contributors to direct green financing, accounting for $74.2 \%$ of the total green financing in Bangladesh. Although state-owned commercial banks (SCBs) contributed just $3.9 \%, 10.3 \%$ of the overall green finance disbursement was provided by the foreign-owned commercial banks (FCBs), while non-bank financial institutions accounted for nearly $12 \%$. Therefore, it can be said that PCBs play a significant role in Bangladesh's green economy growth, and contribute to the achievement of sustainable development goals (SDGs).

In the sustainable economic development of Bangladesh, private commercial banks have been playing a significant role. They provide investment funds to both the public sector and, in particular, the private sector. Therefore, this study only considered PCBs, as they are the sectors with the highest contribution $(74 \%)$ to direct green financing in Bangladesh compared to SCBs, FCBs and NBFIs. Table 3 shows the sector-wise disbursements of green finance by 40 PCBs during the 2014-2019 period in Bangladesh. From Table 3, it can be identified that PCBs were mostly financing solid and liquid waste management $(32.37 \%)$, followed by green brick manufacturing, i.e., fire-burnt brick and non-fire block 
brick (18.52\%), green establishment (15.18\%), recycling and recyclable products $(11.16 \%)$, and others $(11.98 \%)$. On the contrary, renewable energy, energy efficiency and alternative energy investments were the least financed, representing $4.98 \%, 5.66 \%$ and $0.16 \%$ of the total PCBs' green financing from 2014 to 2019 , respectively.

Table 2. Direct green finance by banks and non-bank financial institutions from 2014 to 2019 (amount in million BDT).

\begin{tabular}{ccccccccc}
\hline Institutions & $\mathbf{2 0 1 4}$ & $\mathbf{2 0 1 5}$ & $\mathbf{2 0 1 6}$ & $\mathbf{2 0 1 7}$ & $\mathbf{2 0 1 8}$ & $\mathbf{2 0 1 9}$ & Total GF & Contributions (\%) \\
\hline SCBs (06) & 1700 & 3067.2 & 2013.7 & 2884.4 & 1815.2 & 1219.44 & 12699.94 & 4 \\
\hline PCBs (40) & 23,300 & $20,098.6$ & $24,597.4$ & $30,578.5$ & $65,904.3$ & $78,316.9$ & $24,2795.7$ & 74 \\
\hline FCBs (09) & 9800 & 3273.6 & 768.8 & 551.3 & 192.6 & $19,213.2$ & $33,799.46$ & 10 \\
\hline NBFIs (33) & 9200 & 8320.7 & 5948.2 & 4632.6 & 3389.60 & 6499.87 & $37,990.97$ & 12 \\
\hline Total GF & 44,000 & $34,760.1$ & $33,328.1$ & $38,646.8$ & $71,301.7$ & 105,249 & $327,286.1$ & 100.0 \\
\hline
\end{tabular}

Notes: SCBs, state-owned commercial banks; PCBs, private commercial banks; FCBs, foreign-owned commercial banks; NBFIs, non-bank financial institutions. Source: Authors' compilation from Bangladesh Bank (BB) annual reports and sustainability reports from 2014 to 2019. For more details, see www.bb.org.bd.

Table 3. Sector-wise green finance of private commercial banks (PCBs) during the period 2014-2019 (amount in BDT million).

\begin{tabular}{|c|c|c|c|c|c|c|c|c|}
\hline Sector-Wise Green Finance & 2014 & 2015 & 2016 & 2017 & 2018 & 2019 & Total & $\begin{array}{c}\text { Contributions } \\
(\%)\end{array}$ \\
\hline Renewable energy & 1475.20 & 2284.20 & 1605.00 & 2202.50 & 2605.90 & 1921.36 & $12,094.16$ & 4.98 \\
\hline Energy efficiency & 0.00 & 1400.70 & 2394.30 & 3118.80 & 3156.00 & 3667.96 & $13,737.76$ & 5.66 \\
\hline Waste management * & 1205.63 & 3868.20 & 4338.70 & 8685.50 & $34,914.60$ & $25,571.35$ & $78,583.98$ & 32.37 \\
\hline Alternative energy & 0.00 & 0.00 & 164.80 & 132.70 & 9.00 & 83.98 & 390.48 & 0.16 \\
\hline Green brick manufacturing * & 3546.38 & 5312.80 & 5523.70 & 4839.20 & 9571.40 & $16,172.27$ & $44,965.75$ & 18.52 \\
\hline $\begin{array}{l}\text { Recycling and recyclable } \\
\text { product }\end{array}$ & 400.00 & 2376.80 & 4179.60 & 5813.00 & 3471.30 & $10,852.60$ & $27,093.30$ & 11.16 \\
\hline Green establishment & 1.68 & 1067.50 & 5923.30 & 5650.00 & $10,331.00$ & $13,878.21$ & $36,851.69$ & 15.18 \\
\hline Others & $16,667.18$ & 3788.40 & 467.90 & 136.60 & 1845.10 & 6169.16 & $29,074.34$ & 11.98 \\
\hline Total (amount in BDT million) & $23,296.07$ & $20,098.60$ & $24,597.30$ & $30,578.30$ & $65,904.30$ & $78,316.89$ & $242,791.46$ & 100.00 \\
\hline
\end{tabular}

Notes: * waste management includes solid and liquid waste and green brick manufacturing include fire-burnt brick and non-fire block brick. Source: Authors' compilation from Bangladesh Bank's (BB) annual reports and sustainability reports from 2014 to 2019 . For more details, see www.bb.org.bd.

In 2009, BB established a BDT 2 billion re-financing scheme to support green products such as solar energy, biogas facilities and effluent treatment plants for the development of renewable energy, green industry and environment-friendly related sectors [6]. Initially, six green goods or initiatives were supported under this scheme and facilitated the expansion of the refinancing facility. Subsequently, by 2019 , the central bank has expanded the number of eligible green products/initiatives under the scheme from 6 to 51, considering the consumer's demand and the expert opinions of the technical advisory committee. The total amount spent under the scheme amounted to BDT 2,930.30 million between 2014 and 2019, as shown in Table 4. Besides this, the green industry (35.91\%), biogas (15.10\%), effluent treatment plants $(14.20 \%)$ and brick kiln technology $(10.20 \%)$ are among the most influenced sectors under the scheme. On the other hand, organic manure from slurries $(0.01 \%)$, vermicompost $(0.16 \%)$, solar mini grids $(0.34 \%)$ and energy efficiency technology $(0.81 \%)$ were the least affected sectors during the period 2014-2019. Therefore, we can observe the overall reimbursement under the green products refinancing Table 4. 
Table 4. Bangladesh Bank's refinance scheme for green products from 2014 to 2019 (amount in BDT million).

\begin{tabular}{|c|c|c|c|c|c|c|c|c|}
\hline Category of Green Products & 2014 & 2015 & 2016 & 2017 & 2018 & 2019 & Total & Contribution (\%) \\
\hline Biogas & 212.8 & 83.3 & 84.8 & 46.6 & 10.5 & 4.6 & 442.60 & 15.10 \\
\hline Solar irrigation pump & 17.9 & 26.5 & 0.6 & 0.0 & 0.0 & 0.0 & 45.00 & 1.54 \\
\hline Solar mini-grid & 0.0 & 0.0 & 10.0 & 0.0 & 0.0 & 0.0 & 10.00 & 0.34 \\
\hline Solar home system (SHS) & 32.2 & 87.5 & 14.7 & 35.3 & 0.0 & 0.2 & 169.90 & 5.80 \\
\hline Solar assembly plant & 49.6 & 148.1 & 16.3 & 0.0 & 0.0 & 0.0 & 214.00 & 7.30 \\
\hline Effluent treatment plant & 10.0 & 0.0 & 58.0 & 179.6 & 60.0 & 108.4 & 416.00 & 14.20 \\
\hline Green industry & 0.0 & 0.0 & 400.0 & 0.0 & 500.0 & 152.3 & 1052.30 & 35.91 \\
\hline Organic manure from slurry & 0.0 & 0.0 & 0.2 & 0.1 & 0.0 & 0.0 & 0.30 & 0.01 \\
\hline Vermicompost & 0.0 & 1.1 & 1.6 & 1.3 & 0.0 & 0.8 & 4.80 & 0.16 \\
\hline Paper waste recycling & 0.0 & 0.0 & 20.0 & 20.0 & 0.0 & 0.0 & 40.00 & 1.37 \\
\hline Safe working environment & 0.0 & 0.0 & 35.7 & 55.3 & 82.0 & 40.0 & 213.00 & 7.27 \\
\hline Energy efficient tech & 0.0 & 0.0 & 0.0 & 0.6 & 13.0 & 10.0 & 23.60 & 0.81 \\
\hline HHK technology in brick kiln & 59.0 & 47.0 & 177.8 & 10.0 & 0.0 & 5.0 & 298.80 & 10.20 \\
\hline Total (amount in BDT million) & 381.50 & 393.50 & 819.70 & 348.80 & 665.50 & 321.30 & 2930.30 & 100.0 \\
\hline
\end{tabular}

Source: Authors' compilation from Bangladesh Bank's (BB) annual reports and sustainability reports from 2014 to 2019. For more details, see www.bb.org.bd.

\subsection{Exploratory Factor Analysis}

Table 5 shows the results of the exploratory factor analysis (EFA) using principal component analysis and the reliabilities for all of the study variables [35]. The EFA was employed on 16 items to verify the factor loadings of the constructs, and the number of factors to be obtained was decided by applying the benchmarks of Eigenvalue, according to Cattell (1966). The EFA results showed steadiness in the estimate of three significant dimensions of sustainable finance and sources of sustainable investment. Following the EFA, two items (ENV4 and SGF4) were deleted due to their factor loading being less than 0.5 , and elements cross-loading on the other dimensions. The sample adequacy was confirmed with the Kaiser-Meyer-Olkin (KMO) value of 0.874 , which exceeded the minimum standard level of 0.5 for the factoring value [36]. The Bartlett's sphericity test $(p<0.000)$ was found to be statistically significant, with an approximate chi-square value of 1595.381, indicating the significance of the correlation matrix. Besides this, the dimensions of sustainable finance accounted for $66.298 \%$ of the total variance. Therefore, Cronbach's $\alpha$ values were used to estimate the reliability of each construct, and the values ranged from 0.735 to 806 [37].

\subsection{Confirmatory Factor Analysis (First-Order)}

Using AMOS 23.0, CFA was conducted to validate the goodness of fit indices and 14-item measurements which had been explored using EFA. Besides, the study employed the maximum likelihood estimation method, whereby various statistics such as chi-squared statistic, goodness-of-fit index (GFI), adjusted goodness-of-fit index (AGFI), root mean square error of approximation (RMSEA), comparative fit index (CFI), normed fit index (NFI), incremental fit index (IFI) and Tucker-Lewis index (TLI) were used to access the goodness-of-fit indices [34]. Table 6 shows the outputs of the first-order CFA model $\left(\chi^{2} / \mathrm{df}=1.738, p\right.$-value $=0.000, \mathrm{GFI}=0.946, \mathrm{AGFI}=0.920, \mathrm{RMSEA}=0.049, \mathrm{CFI}=0.967$, $\mathrm{NFI}=0.927, \mathrm{IFI}=0.968$ and TLI $=0.936$ ), suggesting that the goodness-of-fit indices were within acceptable standards. The critical ratios values between 9.026 and 13.104 for all the items specify that the path is significant at the level of 0.001 . The empirical findings showed that the significant dimensions of green finance and sources of green financing 
constructs (Figure 1) are valid and acceptable. As such, the overall model fit is adequate and satisfactory [33].

Table 5. Exploratory factor analysis.

\begin{tabular}{|c|c|c|c|c|c|}
\hline \multicolumn{6}{|c|}{ Factor Loadings } \\
\hline Factor & Items & 1 & 2 & 3 & 4 \\
\hline \multirow{4}{*}{$\begin{array}{c}\text { Factor I } \\
\text { Economic } \\
\text { dimension }\end{array}$} & ECO4 & 0.699 & & & \\
\hline & $\mathrm{ECO} 3$ & 0.770 & & & \\
\hline & $\mathrm{ECO} 2$ & 0.726 & & & \\
\hline & ECO1 & 0.711 & & & \\
\hline \multirow{4}{*}{$\begin{array}{c}\text { Factor II } \\
\text { Social } \\
\text { dimension }\end{array}$} & SOC4 & & 0.700 & & \\
\hline & SOC3 & & 0.672 & & \\
\hline & SOC2 & & 0.787 & & \\
\hline & SOC1 & & 0.805 & & \\
\hline Factor III & ENV3 & & & 0.751 & \\
\hline \multirow{5}{*}{$\begin{array}{l}\text { Environmental } \\
\text { dimension } \\
\text { Factor IV } \\
\text { Sources of } \\
\text { green finance }\end{array}$} & ENV2 & & & 0.780 & \\
\hline & ENV1 & & & 0.695 & \\
\hline & SGF3 & & & & 0.785 \\
\hline & SGF2 & & & & 0.802 \\
\hline & SGF1 & & & & 0.800 \\
\hline \multicolumn{2}{|c|}{ Eigen Value } & 1.535 & 5.449 & 1.013 & 1.284 \\
\hline \multicolumn{2}{|c|}{ Cronbach's alpha } & 0.784 & 0.806 & 0.735 & 0.804 \\
\hline
\end{tabular}

Note: Extraction method: principal component analysis. Rotation method: varimax with Kaiser normalization Variance explained $=66.298 \%, \mathrm{KMO}=0.874$, Bartlett's test of sphericity $=p<0.000$. Source: authors, 2020 .

Table 6. Model estimates and fit indices of first-order CFA.

\begin{tabular}{|c|c|c|c|c|c|c|}
\hline Construct. & Item No & FL & SRW & CR & $p$-Value & Model Fit Indices \\
\hline $\mathrm{ECO} \longrightarrow$ & $\mathrm{ECO} 4$ & 0.68 & 0.681 & * & & \multirow{14}{*}{$\begin{array}{c}\chi^{2} / \mathrm{df}=1.738 \\
p \text {-value }=0.000 \\
\text { GFI }=0.946 \\
\text { AGFI }=0.920 \\
\text { RMSEA }=0.049 \\
\text { CFI }=0.967 \\
\text { NFI }=0.927 \\
\text { IFI }=0.968 \\
\text { TLI }=0.958\end{array}$} \\
\hline $\mathrm{ECO} \longrightarrow$ & $\mathrm{ECO} 3$ & 0.68 & 0.802 & 11.373 & $* * *$ & \\
\hline $\mathrm{ECO} \longrightarrow$ & $\mathrm{ECO} 2$ & 0.73 & 0.733 & 10.699 & $* * *$ & \\
\hline $\mathrm{ECO} \longrightarrow$ & ECO1 & 0.61 & 0.614 & 9.233 & $* * *$ & \\
\hline $\mathrm{SOC} \longrightarrow$ & SOC4 & 0.68 & 0.676 & 11.725 & $* * *$ & \\
\hline $\mathrm{SOC} \rightarrow$ & SOC3 & 0.68 & 0.681 & 11.821 & $* * *$ & \\
\hline $\mathrm{SOC} \rightarrow$ & SOC2 & 0.83 & 0.829 & * & & \\
\hline $\mathrm{SOC} \longrightarrow$ & SOC1 & 0.74 & 0.738 & 12.907 & $* * *$ & \\
\hline $\mathrm{ENV} \longrightarrow$ & ENV3 & 0.66 & 0.658 & * & & \\
\hline $\mathrm{ENV} \longrightarrow$ & ENV2 & 0.69 & 0.685 & 9.026 & $* * *$ & \\
\hline $\mathrm{ENV} \longrightarrow$ & ENV1 & 0.74 & 0.740 & 9.357 & $* * *$ & \\
\hline SGF $\longrightarrow$ & SGF3 & 0.63 & 0.630 & 10.710 & $* * *$ & \\
\hline SGF $\longrightarrow$ & SGF2 & 0.86 & 0.860 & * & & \\
\hline SGF $\longrightarrow$ & SGF1 & 0.78 & 0.785 & 13.104 & $* * *$ & \\
\hline
\end{tabular}

Notes: FL, factor loadings; SRW, standardized regression weight; CR, critical ratio; GFI, goodness-of-fit index; AGFI, adjusted goodness-of-fit index; RMSEA, root mean square error of approximation; CFI, comparative fit index; NFI normed fit index; IFI, incremental fit index; TLI, Tucker-Lewis index, statistically significant at the $p<0.05$ level. Cut-off criteria: $\chi^{2} / \mathrm{df}<5$; GFI $>0.9$; AGFI $<0.90$; RMSEA $<0.08$; CFI $>0.90$; NFI $>0.90$; IFI $>0.90$; TLI $>0.90$ ${ }^{*} p<0.05 ;{ }^{* *} p<0.01 ;{ }^{* * *} p<0.001$. Unstandardized regression weights anticipated as 1 . Significant level at $p<0.05$. 


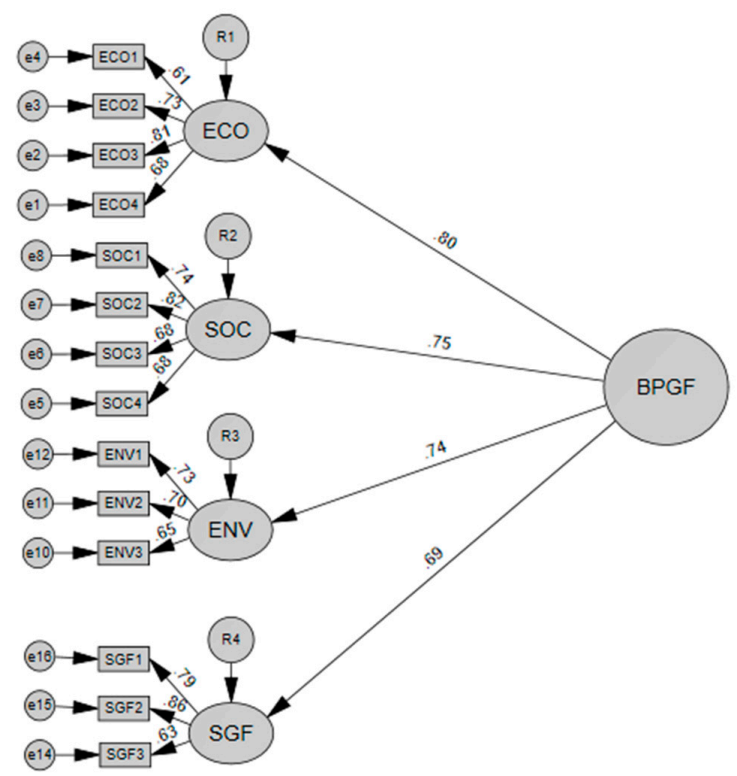

Figure 1. Second-order measurement model. Notes: ECO = economic dimension, SOC = social dimension, $\mathrm{ENV}=$ environmental dimension, $\mathrm{SGF}=$ sources of green financing, and BP = bankers' perception of GF. Source: authors, 2020.

\subsection{Reliability Analysis}

The Cronbach's alpha coefficients (CA) and composite reliability (CR) were utilized to scrutinize the internal consistency and reliability of the green finance constructs. The CA values more than 0.7 were regarded as being reliable, according to Ref. [33]. In line with the present study, the CA values range from 0.735 to 0.806 for all dimensions of green finance, as shown in Table 5. Similarly, the composite reliability of the four factors lies in the range of $0.732-0.822$, which exceeds the acceptable limit of 0.7 [33]. As such, based on the outputs of the CA and CR, it can be concluded that the validity and internal reliability of the factors with their related constructs of the measurement are adequate and satisfactory [38].

\subsection{Discriminant Validity}

Furthermore, the differentiation between the average variance extracted (AVE) square root value and the correlation coefficient among the constructs is adopted to examine the discriminant validity [38,39]. Fornell and Larcker (1981) stated that the values of AVE for the constructs would be above 0.5 if the factor loadings are more than 0.5 for the convergent validity. Fraering and Minor (2006) also observed that the AVE value of 0.4 is considered satisfactory, while the value of 0.30 represents the lowest threshold in social sciences, according to Ref. [33]. Thus, the values of all the factor loadings exceed 0.61, and the values of AVE for all of the constructs are between 0.483 and 0.584 , confirming their reliability $[33,38,40]$, as indicated in Table 7 . The AVE square root value of $0.695-$ 0.764 is higher than their inter-factor correlation. Therefore, it can be concluded that no discriminant validity issues were detected among the factors used in the study (Table 7).

Table 7. Discriminant validity of green finance constructs.

\begin{tabular}{ccccccc}
\hline Dimension & CR & AVE & ECO & SOC & ENV & SGF \\
\hline Economic dimension (ECO) & 0.822 & 0.536 & 0.710 & & & \\
\hline Social dimension (SOC) & 0.840 & 0.569 & 0.335 & 0.733 & & \\
\hline Environmental dimension (ENV) & 0.795 & 0.565 & 0.457 & 0.230 & 0.695 & \\
\hline Sources of green finance (SGF) & 0.835 & 0.633 & 0.250 & 0.364 & 0.220 & 0.764 \\
\hline
\end{tabular}

Diagonal values are AVE root, indicated in italic type, and off-diagonal values are inter-construct squared correlations. 


\subsection{Second-Order CFA Measurement Model}

The second-order measurement model was tested and verified with the results of the CFA [41,42]. To further assess the model, the study employed the various model fit indices and standardized coefficients. Table 8 shows the outputs of the model estimates and fit indices of the dimensions of GF and sources of green financing using a second-order CFA. Besides this, all dimensions in the first-order CFA loaded very well in the second-order CFA for bankers' perceptions of various dimensions of GF and sources of green financing, as indicated in Figure 1. The factor loadings of the second-order CFA measurement model are in the range of $0.61-0.86$ for sustainable finance constructs, which is above 0.5 [33]. Therefore, the empirical findings confirmed the convergent validity for each dimension of GF and sources of green financing, and supported the construct validity [33,43]. Moreover, Table 3 shows the results of the acceptable model fit indices, which are $\chi^{2} / \mathrm{df}=1.887$, $p$-value $=0.000, \mathrm{RMR}=0.042, \mathrm{GFI}=0.940, \mathrm{AGFI}=0.914, \mathrm{RMSEA}=0.054, \mathrm{CFI}=0.959$, $\mathrm{NFI}=0.918, \mathrm{IFI}=0.960$, and TLI $=0.950$ [34]. Therefore, the outputs demonstrated that 14 items of the second-order CFA model of GF dimensions, sources of green financing and bankers' perceptions of green finance in Bangladesh's banking sectors were adequate and satisfactory for the sample data.

Table 8. Model estimates and fit indices of second-order CFA.

\begin{tabular}{ccccc}
\hline Dimension & Factor Loadings & SRW & CR & $p$-Value \\
\hline Economic dimension & 0.80 & 0.805 & $*$ & \\
\hline Social dimension & 0.75 & 0.746 & 7.576 & $* * *$ \\
\hline Environmental dimension & 0.74 & 0.735 & 6.673 & $* * *$ \\
\hline Sources of green financing & 0.69 & 0.687 & 7.378 & $* * *$ \\
\hline
\end{tabular}

Model fit indices: $\chi^{2} / \mathrm{df}=1.887 ; p$-value $=0.000 ; \mathrm{RMR}=0.042 ; \mathrm{GFI}=0.940 ; \mathrm{AGFI}=0.914 ; \mathrm{RMSEA}=0.054 ; \mathrm{CFI}=$ 0.959; NFI $=0.918 ;$ IFI $=0.960 ;$ TLI $=0.950 ;{ }^{*} p<0.05 ;{ }^{* *} p<0.01$; ${ }^{* * *} p<0.001$. Source: authors' 2020.

The outcomes of the study presented the economic dimension as the most significant dimension affecting the level of perceptions of the bankers regarding GF $(\alpha=0.80)$. Therefore, banking institutions, especially private commercial banks in Bangladesh, should maintain a level of awareness and understanding of sustainable finance construct to facilitate the implementation of sustainable investment in Bangladesh. Moreover, the bankers perceived the social and environmental dimensions to be the second and third most crucial factors influencing GF ( $\alpha=0.75, \alpha=0.74)$, followed by sources of green financing $(\alpha=0.69)$. The empirical findings indicate that the level of awareness, beliefs and understanding of the standard dimensions of GF and sources of sustainable investment were satisfactory for the implementation of GF in Bangladesh, as indicated by the bankers of PCBs.

\subsection{Challenges in the Implementation of Green Finance in Bangladesh}

To further determine the major challenges in green finance in Bangladesh, bankers were questioned on their extent of agreement or disagreement with the various challenges influencing the growth of green finance in Bangladesh. Table 9 presents the rank of significant challenges affecting the implementation of green finance by PCBs in Bangladesh. The empirical findings indicated that high transaction costs (mean $=3.61, \mathrm{SD}=0.992)$, heavy default culture (mean $=3.54, \mathrm{SD}=1.176$ ), operational self-insufficiency (mean $=3.52$, $\mathrm{SD}=1.185$ ), improper appraisal of loan applications (mean $=3.50, \mathrm{SD}=1.139)$, absence of adequate accountability and transparency (mean $=3.47, \mathrm{SD}=1.124$ ) are critical challenges stalling the growth and development of green finance in Bangladesh. Other barriers to green finance development in Bangladesh include less flexibility of repayment schedule, with a mean value of 3.44, followed by lack of adequate legal responsibility (mean score is 3.42 ), maturity mismatch (mean $=3.37$ ), lack of green projects assessment skills, with a mean value 3.36 , and poor corporate governance (mean value $=3.30$ ). For the growth and improvement of the country's sustainable economy, green financing remains a key driver; 
therefore, the banking authorities, especially the Bangladesh Bank, should address these critical issues impeding the implementation of green financing by PCBs in Bangladesh.

Table 9. Major challenges affecting the implementation of GF in Bangladesh.

\begin{tabular}{ccccc}
\hline SL & Major Challenges of Green Finance & Mean & $\begin{array}{c}\text { Standard } \\
\text { Deviation }\end{array}$ & Rank \\
\hline 1 & High transaction costs & 3.61 & 0.992 & 1 \\
\hline 2 & Heavy default culture & 3.54 & 1.176 & 2 \\
\hline 3 & Operational self-insufficiency & 3.52 & 1.185 & 3 \\
\hline 4 & Improper appraisal of loan applications & 3.50 & 1.139 & 4 \\
\hline 5 & Absence of adequate accountability and transparency & 3.47 & 1.124 & 5 \\
\hline 6 & Less flexibility of repayment schedule & 3.44 & 0.959 & 6 \\
\hline 7 & Absence of adequate legal responsibility & 3.42 & 1.234 & 7 \\
\hline 8 & Maturity mismatch & 3.37 & 1.128 & 8 \\
\hline 9 & Lack of green projects assessment skills & 3.36 & 1.258 & 9 \\
\hline 10 & Poor corporate governance & 3.30 & 1.119 & 10 \\
\hline Source: Authors'2020.
\end{tabular}

Source: Authors'2020.

\section{Discussion and Conclusions}

In this paper, we set out to identify the bankers' perceptions of various dimensions of green finance, and also identify the major challenges hindering the implementation of green finance in Bangladesh. Besides this, this study presents the current status of green finance in Bangladesh's banks and non-bank financial institutions from 2014 to 2019. With regards to the green financing of the Bangladeshi banking sectors, our findings conform with previous studies which highlighted that both private commercial banks (PCBs) and non-bank financial institutions (NBFIs) have surpassed the foreign-owned commercial banks (FCBs) and state-owned commercial banks (SCBs) $[5,6,26]$. Therefore, it can be said that PCBs play a significant role in the development of Bangladesh's green economy via green financing, thereby contributing to the achievement of sustainable development goals (SDGs). In respect to the sector-wise disbursements of green finance by PCBs during the 2014-2019 periods in Bangladesh, solid and liquid waste management (32.37\%) received the greatest allocation, followed by green brick production, i.e., fire-burnt and non-fire burnt brick $(18.52 \%)$, green establishment $(15.18 \%)$, recycling and recyclable products $(11.16 \%)$, and others $(11.98 \%)$. On the contrary, renewable energy, energy efficiency and alternative energy investments were the least sponsored green projects, representing $4.98 \%, 5.66 \%$ and $0.16 \%$ of the total PCBs' green financing from 2014 to 2019, respectively. These findings are in agreement with other studies [5,6,26]. In addition, BB established a BDT 2 billion re-financing scheme in 2009 to support green products such as solar energy, biogas facilities and effluent treatment plants for the development of the renewable energy, green industry and environment-friendly sectors [6]. Under this scheme, sectors such as the green industry $(35.91 \%)$, biogas $(15.10 \%)$, effluent treatment plants $(14.20 \%)$ and brick kiln technology $(10.20 \%)$ received the most support. On the other hand, organic manure from slurries $(0.01 \%)$, vermicompost $(0.16 \%)$, solar mini grids $(0.34 \%)$ and energy-efficiency technology $(0.81 \%)$ are the sectors to benefit the least from the scheme during the period of 2014-2019. Thus, it can be observed that although the overall reimbursement under the green products refinancing scheme has grown over the years, the growth has been unstable and slow.

To identify the bankers' perceptions regarding various dimensions of green finance and sources of green finance in PCBs, the study utilized EFA and CFA (first-order and second-order) analyses to examine the primary data. Consequently, the study identified three major dimensions of GF (economic, social and environmental) and sources of green financing. The findings clearly illustrate that all these dimensions are discrete but interrelated constructs (first-order CFA). The views of bankers on the aspects of GF and green 
funding sources are therefore considered as a multidimensional framework. The secondorder model (presented in Table 8) also showed good fitness. Moreover, the outcomes of the study suggest that the economic dimension is the most relevant dimensions to the levels of perception of the bankers regarding GF $(\alpha=0.80)$. Therefore, banking institutions such as private commercial banks (PCBs) in Bangladesh should promote the level of awareness and understanding of green finance constructs to facilitate the implementation of green finance, and consequently the achievement of sustainable economic development in Bangladesh. Moreover, the bankers perceived the social and environmental dimensions to be the second and third most crucial factors influencing the GF $(\alpha=0.75, \alpha=0.74)$, followed by sources of green financing $(\alpha=0.69)$. The empirical findings from the bankers of PCBs indicate that the level of awareness, beliefs and understanding of the major dimensions of GF and sources of green financing were adequate for the implementation of green finance in Bangladesh. As such, these findings are in agreement with the past studies (Raihan, 2019; Raihan and Khan, 2018b), which reported a high level of bankers' perceptions of the three essential dimensions of green finance in the context of Bangladesh's PCBs.

In addition, a certain amount of foreign green financing was also discovered in Bangladesh, although it was inadequate. To date, the banking sector and non-bank financial institutions have allocated a certain amount of their investment portfolio towards green projects during the period 2014-2019. The Bangladesh Bank has promoted green project financing via the development of green banking guiding principles, donor-aided industry development projects, on-lending systems, banking institution credit quotas and tax concession refinancing mechanisms. While the guidelines on green banking policy are in place, banks and financial institutions have been improving steadily, especially in terms of their inadequacy in managing green projects [6].

Furthermore, the study also identified the major challenges hindering the development of green finance in Bangladesh. The result shows that the high transaction costs associated with green projects are the key obstacles to the growth of green finance in Bangladesh. Green projects involve different approaches from traditional projects, presenting unusual, specific challenges unique to these projects. Small-scale local businesses find it difficult to access financing because banks will not give them credit until they have demonstrated credit-worthiness. Banks and financial institutions are frequently required to offer loans to small-scale businesses with no proper documentation. Unsolicited applications containing incorrect information from owners or directors with low credit scores are not unusual. As a result, green ventures are burdened with high transaction costs, although the benefits they offer are not very outstanding. Khan et al. [27] also cited similar findings, stating that the benefits of green initiatives are overshadowed by high operational costs. The finding also indicates that the heavy default culture, operational self-insufficiency, improper appraisal of loan applications, and the absence of adequate accountability and transparency are significant hindrances to the development of GF in Bangladesh. Raihan [30] and Hossain [6] supported this observation, indicating the presence of a broad operational and market risk associated with green projects in Bangladesh. Despite the strong externalities and environmental advantages of green projects compared to conventional ones, the lack of professional experience and high costs at early stages pose major threats to the development of green projects $[13,14]$.

Other obstacles of green finance development in Bangladesh include less flexibility in repayment schedules, followed by the absence of adequate legal responsibility, maturity mismatch, lack of green projects assessment skills and poor corporate governance. Bogacheva and Smorodinov [32] also identified similar GF challenges in G20 countries; these include maturity mismatch, the absence of regulatory and legal framework directly related to green finance, lack of analytical tools and expertise for the identification and assessment of risks of green projects, ecological externalities, and the poor selection and management of green project. Therefore, it can be suggested that high transaction costs, heavy default culture, operational self-insufficiency, improper appraisal of loan applica- 
tions, and the absence of adequate accountability and transparency are the major barriers to the development of GF in Bangladesh.

\section{Implications of the Study, Limitations, and Future Research}

The empirical findings offer some useful implications to the financial institutions, managers, bankers, government authorities, clients and investors of Bangladesh to promote GF for the attainment of sustainable development goals (SDGs) in the country. First, in comparison with other banks and non-bank financial institutions, private commercial banks (PCBs) are the largest contributors to direct green financing in Bangladesh. Therefore, it is suggested that the PCBs should be maintained and supported to increase green investment in various eco-friendly projects, and in turn develop the nation. Second, the empirical findings indicate that the level of awareness, beliefs, and understanding of the major dimensions of GF and sources of green financing were satisfactory for the implementation of green finance in Bangladesh. Therefore, banking institutions such as PCBs in Bangladesh should maintain their level of awareness and understanding of GF construct to aid the implementation of GF and the achievement of sustainable economic development in Bangladesh. Besides this, banks should organize a variety of training opportunities, seminars and symposiums so as to increase the workers' and clients' awareness of GF, and the sources of green financing and its benefits. This will essentially make them accustomed to green finance practices. Similarly, Bangladesh Bank must track the compliance of commercial and non-commercial banks with green banking guidelines to promote GF. The government should encourage and educate the public about the benefits of GF as regards the growth of the green economy. Lastly, the findings of the study also showed that high transaction costs, heavy default culture, operational self-insufficiency, improper appraisal of loan applications, and the absence of adequate accountability and transparency are the main obstacles to the development of GF in Bangladesh. In order to minimize the high transaction costs associated with making green loans available to small-scale businesses, a cooperative scheme should be put in place so that small-scale green startups can move together and make collective use of green funding for banks and financial institutions. This would minimize the cost of transactions and the risks involved with financing small businesses who do not have a good credit record, as the community of borrowers will be mutually responsible for paying off the loan. Therefore, the study suggests the need for collaboration between the state, banks, international institutions and business enterprises to address the problems of GF. In this regard, the Bangladesh Bank should play an active role-in educating, organizing, stimulating and monitoring activities related to GF.

Similar to other studies, this research also has some limitations. First, the research was performed on employees of private commercial banks (PCBs), which limits the generalization of the findings. Therefore, the findings of this research could be improved in terms of generalization by evaluating various stakeholders (clients, owners) of banks and non-bank financial institutions. Second, future research may widen the scope of this study by examining the effect of the environmental performance and profitability of the bank on the different dimensions of GF and green financing sources. Third, the bankers' perceptions of each dimension of the GF construction may differ between state-owned commercial banks (SCBs), Islamic banks, foreign-owned commercial banks and non-bank financial institutions (NBFIs). As such, this could be investigated in future study through various industries. Finally, the study has only taken the bankers' opinions regarding various aspects of green financing, rather than the opinions of the clients and owners of the sample banks.

Author Contributions: conceptualization, A.B.S.; methodology, A.B.S., G.-W.Z., M.M., S.S.A., and N.F.; software, A.B.S., G.-W.Z., and M.M.; validation, G.-W.Z., A.B.S., and M.M.; investigation, M.M., A.B.S. and N.F.; resources, A.B.S., S.S.A., and M.M.; data curation, M.M., A.B.S., and N.F.; writingoriginal draft preparation, A.B.S., and M.M.; writing-review and editing, G.-W.Z., S.S.A.,N.F., and M.M.; visualization, N.F., A.B.S. and M.M.; supervision, G.-W.Z., S.S.A., and M.M.; Funding acquisition, G.-W.Z. All authors have read and agreed to the published version of the manuscript. 
Funding: This research was funded by the Ministry of Education of the People's Republic of China, Grant Number is 20XJC790015. And APC was funded by the same grant.

Institutional Review Board Statement: Not applicable.

Informed Consent Statement: Not applicable.

Data Availability Statement: The data that support the findings of this study are available from the corresponding authors (A.B.S and S.S.A) upon reasonable request.

Acknowledgments: The researchers would like to express their gratitude to the anonymous reviewers for their efforts to improve the quality of this paper.

Conflicts of Interest: The authors declare no conflict of interest.

\section{References}

1. Liu, N.; Liu, C.; Xia, Y.; Ren, Y.; Liang, J. Examining the Coordination Between Green Finance and Green Economy Aiming for Sustainable Development: A Case Study of China. Sustainability 2020, 12, 3717. [CrossRef]

2. Lewis, J.I. Green Innovation in China: China's Wind Power Industry and the Global Transition to a Low-Carbon Economy; Columbia University Press: New York, NY, USA, 2012.

3. Ngwenya, N.; Simatele, M.D. The emergence of green bonds as an integral component of climate finance in South Africa. S. Afr. J. Sci. 2020, 116, 10-12. [CrossRef]

4. Nawaz, M.A.; Seshadri, U.; Kumar, P.; Aqdas, R.; Patwary, A.K.; Riaz, M. Nexus between green finance and climate change mitigation in N-11 and BRICS countries: Empirical estimation through difference in differences (DID) approach. Environ. Sci. Pollut. Res. 2020, 1-16. [CrossRef]

5. Akter, N.; Siddik, A.B.; Mondal, S.A. Sustainability Reporting on Green Financing: A Study of Listed Private Sustainability Reporting on Green Financing: A Study of Listed Private Commercial Banks in Bangladesh. J. Bus. Technol. 2018, $12,14-27$.

6. Hossain, M. Handbook of Green Finance, Sustainable Development; Springer: Singapore, 2019; pp. 1-26.

7. Zhang, D.; Zhang, Z.; Managi, S. A bibliometric analysis on green finance: Current status, development, and future directions. Financ. Res. Lett. 2019, 29, 425-430. [CrossRef]

8. Haque, M.S.; Murtaz, M. Green Financing in Bangladesh. In Proceedings of the International Conference on Finance for Sustainable Growth and Development, Chittagong, Bangladesh, 15 March 2018; pp. 82-89.

9. Dörry, S.; Schulz, C. Green financing, interrupted. Potential directions for sustainable finance in Luxembourg. Local Environ. 2018, 23, 717-733. [CrossRef]

10. Recent Advances in Green Finance. Int. J. Recent Technol. Eng. 2020, 8, 5528-5533. [CrossRef]

11. Wang, Y.; Zhi, Q. The Role of Green Finance in Environmental Protection: Two Aspects of Market Mechanism and Policies. Energy Procedia 2016, 104, 311-316. [CrossRef]

12. Fedorova, E.P. Role of the State in the Resolution of Green Finance Development Issues. Financ. J. 2020, 12, 37-51. [CrossRef]

13. Zaidi, S.A.H.; Zafar, M.W.; Shahbaz, M.; Hou, F. Dynamic linkages between globalization, financial development and carbon emissions: Evidence from Asia Pacific Economic Cooperation countries. J. Clean. Prod. 2019, 228, 533-543. [CrossRef]

14. Tolliver, C.; Keeley, A.R.; Managi, S. Green bonds for the Paris agreement and sustainable development goals. Environ. Res. Lett. 2019, 14, 064009. [CrossRef]

15. Jha, B.; Bakhshi, P. Green Finance: Fostering Sustainable Development in India. Int. J. Recent Technol. Eng. 2019, 8, 3798-3801. [CrossRef]

16. Shalneva, M.S.; Zinchenko, Y.V. Sustainable Finance as a Way of European Companies' Transition to Green Economy; Springer: Cham, Switzerland, 2018; Volume 57, pp. 1002-1012.

17. Liebman, A.; Reynolds, A.; Robertson, D.; Nolan, S.; Argyriou, M.; Sargent, B. Green Finance in Indonesia. In Handbook of Green Finance; Sachs, J., Thye, W.W., Yoshino, N., Taghizadeh-Hesary, F., Eds.; Springer: Singapore, 2019; pp. 1-30.

18. Schäfer, H. Germany: The 'Greenhorn' in the Green Finance Revolution. Environ. Sci. Policy Sustain. Dev. 2017, 60, 18-27. [CrossRef]

19. Ren, X.; Shao, Q.; Zhong, R. Nexus between green finance, non-fossil energy use, and carbon intensity: Empirical evidence from China based on a vector error correction model. J. Clean. Prod. 2020, 277, 122844. [CrossRef]

20. Zhixia, C.; Hossen, M.; Muzafary, S.S.; Begum, M. Green Banking for Environmental Sustainability-Present Status and Future Agenda: Experience from Bangladesh. Asian Econ. Financ. Rev. 2018, 8, 571-585. [CrossRef]

21. Zhou, X.; Tang, X.; Zhang, R. Impact of green finance on economic development and environmental quality: A study based on provincial panel data from China. Environ. Sci. Pollut. Res. 2020, 27, 19915-19932. [CrossRef]

22. Wang, K.; Lu, Y.; Du, X.; Bi, D. Internet Finance, Green Finance, and Sustainability. Sustainability 2019, 11, 3856. [CrossRef]

23. Mohd, S.; Kaushal, V.K. Green Finance: A Step towards Sustainable Development. Mudra J. Financ. Account. 2018, 5, 59-74. [CrossRef]

24. Akter, A.; Himo, R.H.; Siddik, A.B. Corporate Bond Market: The Case of Bangladesh. World Rev. Bus. Res. 2019, 9, $20-38$.

25. Hossain, M. Green Finance in Bangladesh: Policies, Institutions, and Challenges. Adbi Work. Pap. Ser. 2018, 892, 1-24. 
26. Hoque, N.; Mowla, M.; Uddin, M.S.; Mamun, A.; Uddin, M.R. Green Banking Practices in Bangladesh: A Critical Investigation. Int. J. Econ. Financ. 2019, 11, 58-68. [CrossRef]

27. Khan, A.; Khan, B.; Uddin, N.; Azim, G.; Islam, S. Financing Green Growth in Bangladesh: Challenges \& Opportunities; Green Growth Knowledge Platform; UKAID: Dhaka, Bangladesh, 2017.

28. Falcone, P.M.; Sica, E. Assessing the Opportunities and Challenges of Green Finance in Italy: An Analysis of the Biomass Production Sector. Sustainability 2019, 11, 517. [CrossRef]

29. Raihan, M.Z.; Khan, M.S.U. Finance for Sustainable Growth and Development; Department of Finance, Faculty of Business Administration, University of Chittagong: Chittagong, Bangladesh, 2018; pp. $29-49$.

30. Raihan, M.Z. Sutainable Finance for Growth and Development of Banking Industry in Bangladesh: An Equity Perspective. Mist. J. Sci. Technol. 2019, 7, 41-51.

31. Tolliver, C.; Fujii, H.; Keeley, A.R.; Chapman, A.J. Green Innovation and Finance in Asia. Asian Econ. Policy Rev. $2020,1-21$. [CrossRef]

32. Bogacheva, O.; Smorodinov, O. Challenges to Green Finance In G20 Countries. World Econ. Int. Relations 2017, 61, 16-24. [CrossRef]

33. Hair, J.F.; Black, W.C.; Babin, B.J.; Anderson, R.E. Multivariate Data Analysis, 4th ed.; Prentice Hall: New Jersey, NJ, USA, 2010.

34. Hu, L.T.; Bentler, P.M. Cutoff criteria for fit indexes in covariance structure analysis: Conventional criteria versus new alternatives. Struct. Equ. Model. 1999, 6, 1-55. [CrossRef]

35. Osborne, J.W.; Costello, A.B. Best practices in exploratory factor analysis: Four recommendations for getting the most from your analysis. Pr. Assess. Res. Eval. 2005. [CrossRef]

36. Spicer, J. Making Sense of Multivariate Data Analysis: An Intuitive Approach; Sage Publications: Thousand Oaks, CA, USA, 2005.

37. Nunnally, J.; Bernstein, I. Psychometric Theory, 3rd ed.; Mcgraw-Hill: New York, NY, USA, 1994.

38. Fornell, C.; Larcker, D.F. Evaluating Structural Equation Models with Unobservable Variables and Measurement Error. J. Mark. Res. 1981, 18, 39. [CrossRef]

39. Chin, W. The Partial Least Squares Approach to SEM chapter. Mod. Methods Bus. Res. 1998, 295-336.

40. Fraering, M.; Minor, S.M. The Virtcomm scale: A virtual community measurement tool. In Proceedings of the American Marketing Association Summer Educators Conference Proceedings, Chicago, IL, USA, 4-7 August 2006.

41. Gerbing, D.W.; Anderson, J.C. An updated paradigm for scale development incorporating unidimensionality and its assessment. J. Mark. Res. 1988, 25, 186-192. [CrossRef]

42. Byrne, B.M. Structural Equation Modeling With AMOS, EQS, and LISREL: Comparative Approaches to Testing for the Factorial Validity of a Measuring Instrument. Int. J. Test. 2001, 1, 55-86. [CrossRef]

43. Amin, M.; Isa, Z. An examination of the relationship between service quality perception and customer satisfaction. Int. J. Islam. Middle East. Financ. Manag. 2008, 1, 191-209. [CrossRef] 